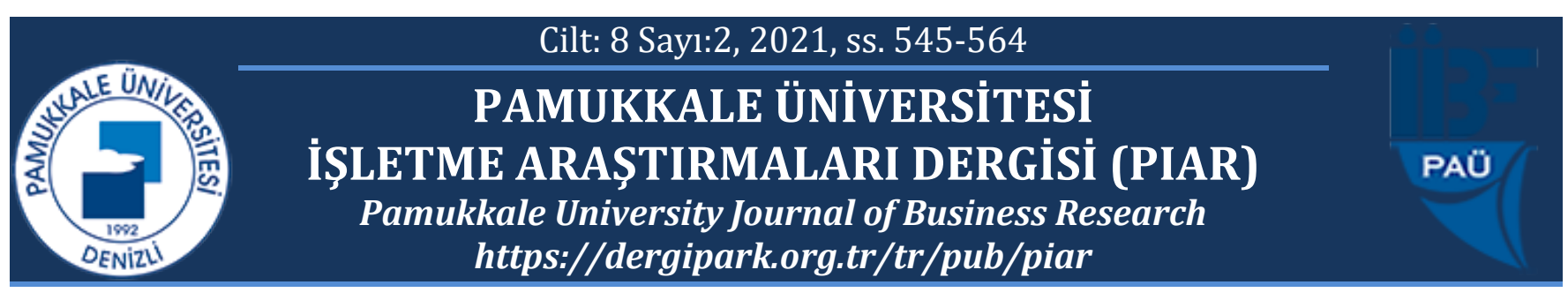

\title{
Bankacılık Sektöründe Çözümleme Maliyetinin Hesaplanması
}

\author{
Calculating Resolution Cost in Banking Sector
}

\section{Ferhun ATEŞ ${ }^{1^{*}}$}

\author{
1 Ankara Üniversitesi Sosyal Bilimler Enstitüsü, İşletme ABD Doktora Öğrencisi, ferhunates@gmail.com, \\ https//orcid.org/0000-0001-8713-4930 \\ ${ }^{2}$ Ankara Üniversitesi Siyasal Bilgiler Fakültesi, sayilgan@ankara.edu.tr, https//orcid.org/0000-0002-4214-7321 \\ * Yazışılan Yazar/Corresponding author
}

Makale Geliş/Received: 8.11.2021

Makale Kabul/Accepted: 14.12.2021

\section{Öz}

Finansal Sektörde yaşanan krizler neticesinde küresel ölçekli birçok banka iflas noktasına gelmiştir. Bunlardan bazıları devletler eliyle kurtarlmış ancak bu kurtarma süreci ekonomiye ve dolayısıyla vergi ödeyenlere önemli ölçüde yük getirmiştir. Diğger taraftan, batış sürecine giren bankalar da kredilendirme tarafinda reel sektörü ciddi biçimde etkilediği için batık bankaların ekonomi üzerindeki maliyeti de önemli boyutlara ulaşmıştır. Dolayısıyla özellikle global finans krizinden sonraki dönemde Bankacılıkta makro ihtiyatl politikalar çerçevesinde Bankalarm iflas noktasına gelmeden önce alınan tedbirlerle batmasının önü alınmaya çalışılmıştır. Bu anlamda bankalarm iflas noktasina gelmesinde ortaya çıkacak maliyet önem kazanmış ve bu alanda çalışmalar yapılmıştır.

Son yıllarda yabancı literatürde olası bir çözümleme durumunda karşı karşıya kalınacak maliyetlerinin hesaplanmasına yönelik çalışmalar yapılmaktadır. Araştırmalarımızda, çözümlemenin maliyetleri konusunda Türkçe ve Türk Bankacilık sektörü hakkında çalışmaya rastlanılmamıştır. Bu çalışmada, Türk bankacılık sektörünün bir çözümleme süreci ile karşı karşıya kalması durumunda meydana gelebilecek çözümleme maliyetinin hesaplanması hedeflenmiştir. Bu kapsamda, hesaplan çözümleme maliyetlerinin 2004 yılından 2015 yılına kadar önemli ölçüde artış eğilimi gösterdiği görülmektedir. 2015'ten sonra dönemde hesaplanan çözümleme maliyetinde bir düşüş eğilimi görülmekte olup Basel 3 standartlarına uyum çalışmaları çerçevesinde Bankaların özkaynak ve SYR'lerinin yüksek tutulmasina ilişkin yapılan ilave sermaye tamponları bulundurulması benzeri düzenlemelerin etkili olduğu düşünülmektedir.

Anahtar kelimeler: Bankacılı, Çözümleme, Sistemik Risk, Çözümleme Maliyeti

JEL kodları: G21, G28, G33

\section{Güven SAYILGAN²}

\begin{abstract}
As a result of the crises in the financial sector, many global banks have come to the point of bankruptcy. Some of these were saved by the states, but this recovery process brought a significant burden to the economy and therefore to taxpayers. On the other hand, as the banks that entered the bankruptcy process seriously affected the real sector on the lending side, the cost of the failed banks on the economy reached significant levels Therefore, especially in the period after the global financial crisis, within the framework of macro-prudential policies in banking, it was tried to prevent the bankruptcy of banks with the measures taken before they came to the point of bankruptcy. In this sense, the cost that will arise in the bankruptcy of banks has gained importance and studies have been carried out in this area.

In recent years, studies have been carried out to calculate the costs of resolution in the foreign literatüre. In our research, no study has been found about the costs of analysis in Turkish and the Turkish banking sector. In this study, it is aimed to calculate the resolution cost that may occur in case the Turkish banking sector is faced with a resolution process. In this context, it is seen that the calculated resolution costs have a significant increasing trend from 2004 to 2015. There is a decreasing trend in the resolution cost calculated in the period after 2015, and it is thought that regulations such as keeping additional capital buffers for keeping the equity and CAR of the banks high within the framework of efforts to comply with Basel 3 standards are effective.
\end{abstract}

Keywords: Banking, Resolution, Systemic Risk, Resolution Cost JEL codes: G21, G28, G33 


\section{GİRIŞ}

Güçlü bir bankacılık sektörü, güvenli ve düzenli bir şekilde faaliyet gösteren sağlıklı yapıya sahip bankalardan oluşmaktadır. Sorunlu hale gelen bankaların denetim ve gözetim otoriteleri tarafından hızlı bir biçimde rehabilite edilmesine yönelik operasyonların gerçekleştirilmesi ve sisteme yeniden kazandırılması rehabilite edilemeyen bankaların, banka müşterilerinin karşı karşıya kaldığı sorunların en aza indirilmesi ve bankacılık sektöründe yaşanan problemlerin diğer finansal kuruluşlara da sirayet etmesini önlemek için gecikmeden sistemden çıkarılmasının gerekliliği bugüne kadar çeşitli ülkelerde yaşanan finansal krizler neticesinde anlaşılmıştır. Söz konusu krizlerde banka batışlarının ülke ekonomilerine çok ciddi maliyet getirdiği de açıtır.

$\mathrm{Bu}$ itibarla, bankacılık sisteminin ne kadar sağlıklı bir yapıda olursa olsun olası bir krizde sektörün çözümlenmesi için gerekli kaynakların büyüklüğünün, bir başka deyişle bankacılıkta çözümleme maliyetinin belirlenmesinin önem arz ettiği düşünülmektedir.

Bankacılık sektöründe olası bir çözümleme maliyetinin belirlenmesinin ayrıca hem bankalar hem de finansal sistemin denetim ve düzenlemesinden sorumlu otoriteler açısından da ileriki dönemlerde politika belirleme çalışmalarında ayrıca bir önem taşıyacağı ve bu alanda yapılacak çalışmalara katsı sağlayacağında inanılmaktadır.

Bu kapsamda, çalışmamızda bankacılıkta sistemik risk ve çözümleme maliyetinin belirlenmesine ilişkin akademik çalışmalar taranmış ve bankacılık sektörünün mevcut durumda bir kriz yaşaması ve bankaların iflas noktasına gelmesi durumunda sektörün çözümlenmesi için gereken kaynağın ne tutarda olacağına ilişkin bir analitik değerlendirme yapılmış olup, Türk Bankacılık sektörü için uygun bir modelle çözümleme maliyetinin tahmin edilmesine çalışılmıştır.

Literatür taraması yapılırken bugüne kadar Türkiye' de çözümleme konusuna ilişkin yapılan bir akademik çalışmaya rastlanmamıştır. Bu anlamda çalışmamızın, çözümleme maliyetinin hesaplanması üzerine yapılan ilk çalışma olduğu düşünülmektedir.

\section{BANKACILIK SEKTÖRÜNDE SISTEMIKK RİSK VE ÇÖZÜMLEME MALIYYTININN BELİRLENMESİNE İLIŞKİN ÇALIŞMALAR}

Küresel finansal krizler çeşitli dönemlerde görüldügünden dünyada finansal krizlerin etkileri üzerine yapılan çok sayıda çalışma bulunmaktadır. Özellikle son dönemde yapılan çalışmalarda, 2008 yılındaki finansal kriz sonrası çok tartışılmaya başlanan finansal sistemin taşıdığ1 riskin ve finansal kuruluşların bu riske katkısının ölçülmesine de ağırlık verilmiştir. Bu alandaki çalışmalar özellikle "batmayacak kadar büyük" kavramından da hareketle sistemik risk taşıyan bankalar ve bu bankaların riske maruz değerleri üzerinden yapılmaktadır. Doğrudan çözümleme maliyeti hesaplamasına ilişkin yapılan çalışmalar ise çok fazla sayıda değildir. Bu nedenle literatür taraması yapılırken bankaların veya bankacılık sektörünün çözümleme maliyetine ilişkin çalışmaların yanı sıra bankaların sistemik riske katkısını hesaplamaya yönelik çalışmalar da taranmıştır. Bankaların sistemik riske olan katkısı hesaplanırken, bu hesaplamanın bir anlamda bu bankaların herhangi bir kriz veya batma durumunda ne seviyede bir kayıp yaşayacağı ve bu bankaların çözümleme kapsamına girmesi durumunda ne kadar bir maliyete neden olacağ 1 konusunda da bir gösterge olduğu düşünülmektedir. 
Literatürde yer alan bankaların çözümleme maliyetini hesaplama ve sistemik riske katkısını hesaplamaya yönelik yapılan çalışmaların aşağıda sunulmuştur:

\subsection{Bankaların Çözümleme Maliyetinin Hesaplanmasına İlişkin Çalışmalar}

Grimaldi vd. (2016) çalışmalarında, hem bir bankanın iflas etmesi durumunda ortaya çıkabilecek beklenen maliyetleri ("ex-post" maliyetler) hem de bankanın çözümleme sürecine girmesi durumunda bankanın çözümüyle ilişkili geleceğe ilişkin maliyetleri (ex-ante maliyetler) hesaplamaya çalışmışlardır. Burada banka başarısızlığının sonradan maliyeti, toplam çözüm maliyetlerinin bir ölçüsü olarak değerlendirilmiş, bir bankanın başarısız olduktan sonra çözülmesinin doğrudan finansal maliyeti olarak tanımlanmıştır. Diğer bir deyişle, harcama sonrası, ödeme aczine düşen bir bankayı yeniden çözüme kavuşturulduğu noktaya döndürmek için gereken acil maliyete eşdeğerdir. Bu noktada bankanın varlıklarının piyasa değerinin en azından toplam yükümlülüklerine eşit olduğu çıkarımı yapılmıştır. Buna göre borca batık bir banka, banka alacaklılarının zararı kabullenmeleri yoluyla çözülürse, çözümleme maliyeti, özkaynağın gerçeğe uygun değerinin toplam yükümlülüklerden düşülerek, bankanın kalan borcunun toplam değerine eşittir. Diğer taraftan, bir banka bir kurtarma yoluyla çözülürse, maliyet, kurtarma noktasında özkaynakların gerçeğe uygun değerine eşittir. Grimaldi vd. (2016) çalışmalarında, örnekleme alınan bankalar için beklenen harcama sonrası maliyetler, her bir bankanın toplam yükümlülüklerinin, bankanın çözümde karşılaşması beklenen temerrütte zarar (LGD) tahmini ile çarpılmasıyla tahmin edilmiştir.

Bahse konu çalışmada, 2008 kriz dönemi ve sonrası içinde Türkiye'nin de bulunduğu 25 OECD ülkesinden 212 bankanın verileri temel alınmış olup, beklenen çözüm maliyetlerinin 2008 sonrası dönemde daha yüksek ortalama sermaye oranları ve GSYİH'ın yüzdesi olarak daha düşük seviyede gerçekleşen banka yükümlülükleri nedeniyle düştügü bulunmuştur. 2008'den hemen sonra keskin bir şekilde artan bu beklenen çözüm maliyetlerinin (ön maliyetler) yıllıklandırılmış değeri, o zamandan beri azalmış, ancak 2008 seviyesinin oldukça üzerinde kalmıştır. Genel olarak, üretilen tahminler, makro ihtiyati tedbirler anlamında mali sektör reformlarının, vergi mükelleflerine beklenen maliyetler de dahil olmak üzere, banka başarısızlığıyla ilişkili maliyetleri azaltmada bir etkisi olduğu fikrini desteklemektedir. Bununla birlikte, beklenen maliyet tahminlerinin çoğu durumda henüz kriz öncesi seviyelere dönmediği de görülmüştür.

Söz konusu çalışmada çözümleme maliyetleri hesaplanmaya çalışılırken iki farklı tahmin yöntemi kullanılmaktadır. Bunlardan ilk yaklaşım, bazı belirli yıllar için kesitsel bilgileri kullanmakta ve Snethlage (2015) tarafından Yeni Zelanda'daki sistemik olarak önemli bankalara uygulanan Merton tarafından uyarlanan Black\&Scholes opsiyon fiyatlandırma modeline dayanarak banka batışlarında risk ve maliyeti ölçmeyi hedeflemektedir. İkinci yaklaşım ise, nispeten yüksek frekansta mevcut olan finansal piyasa verilerinden çıkarımlar yapmak için koşullu talep analizini kullanmakta ve piyasa değerlerindeki dalgalanmayı da dikkate alarak bankaların riske maruz değerini ve dolayısıyla batma olasılığı durumunda meydana gelecek kaybı hesaplamaktadır.

Genel olarak, bu çalışmada ulaşılan sonuçlar, krizden sonra yapılan mali sektör reformlarının, vergi mükellefleri için beklenen maliyetler de dâhil olmak üzere, banka başarısızlığıyla ilişkili maliyetleri azaltmada bir etkisi olduğu fikrini desteklemektedir. 
Bununla birlikte, tahminlerin çoğu durumda henüz kriz öncesi seviyelere dönmediği sonucuna varılmış ve reformlar devam ederken ve krizden etkilenen ekonomiler toparlanmaya devam ederken bu göstergelerin iyileşmeye devam etmesinin beklendiği belirtilmiştir.

Grimaldi \& Linder (2018), İsveç Ulusal Borçlanma Ofisi adına yaptıkları çalışmalarında; şarta bağlı alacak analizi ilgili literatüre dayalı olarak, Avrupa bankalarından seçilmiş bir örneklem için banka çözüm maliyetlerini belirleyip tahmin etmeye çalışmakta, daha sonra, düzenleyiciler tarafından çözüm maliyetlerinin zaman içindeki değişimini izlemek için kullanılabilecek, ülkeler bazında bankacılık sistemi için bir çözüm maliyeti ölçümü önermektedirler. Bunu yaparken de finansal sıkıntı durumunda banka alacaklılarının karşılaması gereken doğrudan maliyetlere odaklanmaktadırlar.

Çalışmalarında, banka çözüm maliyetlerini ölçmek için kullandıkları analizde bankaların finansal sıkıntısı ve sistemik risk literatürü temel almışlardır. Kullandıkları yöntemin temelinde de Black \& Scholes (1973) ve Merton (1974) tarafından öncülük edilen şarta bağlı alacak analizi (Contingent Claims Analysis) yaklaşımı (CCA) yatmaktadır.

Grimaldi \& Linder çalışmalarında bankacılık sektörünün \% 80 büyüklüğünü oluşturan dört büyük İsveç Bankasını ve hisseleri halka açık olan 24 Avrupa bankasını dikkate almışlardır. Analizlerini hem dört İsveç bankası için ayrı hem de Avrupa bankaları için ayrı yapmışlardır. Bunun dışında da analize dâhil ettikleri bankaların ülkeleri bazında da çözümleme maliyeti hesaplamışlardır. Bu kapsamda, 2008-2009 döneminde, analize dâhil ettikleri tüm Avrupa bankalarının çözüm maliyetlerinin önemli ölçüde arttığı sonucuna ulaşmışlardır. Finansal krizden sonra, çözüm maliyetlerinin tüm bankalar için azaldığını gözlemlemişlerdir.

Çalışmanın ampirik sonuçlarının, mali istikrara yönelik artan risklere işaret eden ve politika müdahaleleri gerektirebilecek çözüm maliyetlerindeki artışlar konusunda düzenleyicileri uyarabilme etkisi olduğunu belirtmişlerdir. Ayrıca, özkaynak ve ayrıcalıklı borçlar için düzenleyici asgari sermaye gereksinimin (MREL=minimum amount of equity and subordinated debt gerekliliği) belirlenmesi için genel analize yardımcı olmak için de kullanılabileceğini ileri sürmüşlerdir. Çalışmada özellikle Avrupa Birliği Kurtarma ve Çözümleme Direktifine atıfta bulunarak bu direktifin Avrupa ülkeleri genelinde banka çözüm maliyetlerinin belirlenmesinde temel bir öneme sahip olduğunu belirtmişlerdir.

Cariboni vd. (2016) ise çalışmalarında; Avrupa bankacılık sektöründeki başarısızlıklardan kaynaklanan olumsuz dışsallıkları sınırlama çabaları ile ilgili şartlı yükümlülüklerin yeni düzenlemenin bir sonucu olarak önemli ölçüde azaldığı ancak zararların vergi mükelleflerinden banka alacaklılarına zımni kaydırılmasından hareketle, banka zararların ortadan kalkmadığı kabul edilmiştir. Banka kurtarma veya çözüm kayıplarının hangi noktalara varacağını tartışmışlardır. Çalışmalarında doğrudan bankacılık sektöründeki sıkıntılardan doğabilecek zararlara odaklanmakta ve bu kayıpların finansal güvenlik ağı katılımcıları arasında nasıl paylaşılabileceğini incelemişlerdir.

Cariboni vd. çalışmalarında Avrupa Birliği bankacılık sektörüne hükümetlerin şarta bağlı yükümlülüklerinin boyutunu değerlendiren Avrupa Komisyonu modeli SYMBOL'ü (Systemic Model of Banking Originated Losses = Banka Kaynaklı Zararların Sistemik Modeli) 
kullanmışlardır. SYMBOL modeli bir her bir bankadan başlayarak bankacılık sistemindeki kayıpların dağılımını simüle eden bir mikro simülasyon modeli olarak geliştirilmiştir.

Model, bankaların asgari sermaye gereksinimleri için Basel düzenlemelerini esas almakta olup, banka bazında zararlar, her bir bankanın portföyündeki borçluların ortalama temerrüt riskinin tahminine, temelde toplam varlıklarının ve risk ağırlıklı varlıklarının bir fonksiyonuna bağlıdır. Bir bankanın başarısızlığı, simüle edilen zararların boyutu ve beklenmedik şokları absorbe etmek için gerekli düzenleyici sermaye ile belirlenmektedir. Kayıplar, Basel İçsel Derecelendirme yöntemi kullanılarak Monte Carlo simülasyonları aracılığıyla oluşturulmuştur.

Model, AB Sermaye Gereksinimleri Direktifinin (Avrupa Komisyonu, 2014a), Banka Kurtarma ve Çözümleme Direktifinin (Avrupa Komisyonu, 2014b) etki değerlendirmelerini hazırlamak için Avrupa Komisyonu tarafından kullanılmıştır.

SYMBOL modeli, sermayeyi aşan banka zararları ile düzenlemenin getirdiği asgari sermaye şartının yerine getirilmesi ile ilgili banka yeniden sermayelendirme ihtiyaçları arasında ayrım yapmaktadır. Bu özellik, iki türlü finansman ihtiyacını karşılamak için kamu fonlarının bankacılık sektörüne nasıl enjekte edileceğini ayırt etme ve kamu maliyesi üzerindeki etkileri açısından farklı muamele etme olanağı sağlamaktadır. Sermayeyi aşan banka zararları, bankacılık sektöründeki likidite enjeksiyonları (sübvansiyonlar) ile karşılanabilir, bu da kamu açığını ve borçlanmasını etkilemektedir. Yeniden sermayelendirme ihtiyaçları, hükümet tarafından sorunlu finansal varlıkların satın alınmasıyla karşılanabilir. $\mathrm{Bu}$, söz konusu varlıklardan geri kazanılabilir olması beklenebilecek miktara kadar normal bir mali işlem olarak görülebilir bu nedenle ikinci yolda birincisinin aksine, telafi edilmesi ve böylece daha sonraki bir aşamada kamu maliyesinin "yeniden bütünleştirilmesi" beklenebilir.

Carboni vd. (2016) çalışmalarında, alternatif sermaye seviyeleri ve farklı güvenlik ağ araçlarının dikkate alındığı bir dizi "ne olursa olsun" senaryosu uygulamışlardır. Bu senaryolarda dikkate alınan araçlar aşağıda açıklanmaktadır;

- Daha Yüksek sermaye; Yalnızca beklenen zararları karşılayan cari sermayeyi dikkate almanın yanı sıra, minimum sermaye seviyesini risk ağırlıkl varlikların \% 10,5'ine yükselten Basel III sermaye koruma tamponunu takiben artan Asgari Sermaye Benzeri Borç Gereksinimleri (MREL) seviyesine gelmek için gerekli sermaye miktarın göz önünde bulundurmuşlardır.

- Otofinansman; Her bir bankanın sahip olduğu teminatsız borç miktarına ilişkin veri bulunmadığından, bankaların toplam varlıklarının \% 8'ine eşit bir minimum Kayıp Karşılama Kapasitesine $(L A C=$ Loss-Absorbing Capacity $=$ Toplam Düzenleyici Sermaye Artı Diğer Teminatsız Yükümlülükler) sahip olduğu varsayılmaktadır. Çözüm fonları ancak kayıpları absorbe etmek için halihazırda banka fonlarının en az\% 8'i kullanılmısssa devreye sokulabileceğinden, asgari eşik mevcut düzenlemelere uygun olarak seçilmiştir. Uygulamada, toplam sermayesi toplam \% 8'in altında olan tüm bankalar için bu eşiğin altında kalan sermaye ihtiyacının, otofinansman yoluyla karşılandığ $ı$ varsayılmaktadır. Bir bankanın bu eşiğin üzerinde sermaye tutması durumunda, otofinansman işlemi olmayacak ve sermayenin tamamı kayıpları karşılamak için kullanılacaktır. 
- Çözümleme fonları. Hem tüm bankacılık birliği için tek bir çözümleme fonunun mevcut olduğu tek bir çözüm fonunun hem de fonların yalnızca yerel düzeyde mevcut olduğu ulusal çözümleme fonlarmın etkilerini dikkate almışlardır. Çözüm fonlarındaki fon miktarı, mevzuata uygun olarak, Avrupa bölgesindeki toplam teminatl mevduat tutarmın \% 1'ine eşittir.

Yukarıda bahsi geçen çalışmalar özellikle bankaların sıkıntıya girmesi durumunda gerekli sermaye ihtiyacını belirlemeye yoğunlaşmışlar ve bunu hesaplamak için bankaların olası kayıplarını hesaplamaya odaklanmışlardır.

\subsection{Sistemik Risk Üzerine Yapılan Çalışmalar}

Literatürde bankaların çözümleme maliyetlerine ilişkin çalışmaların yanı sıra bazı araştırmacılar da çalışmalarını sistemik risk üzerine yoğunlaştırmışlardır. Sistemik risk, bir finansal kuruluşun yükümlülüklerini karşılama konusunda başarısız olması ve çöküş sürecine girmesinin bir zincirleme etki ile diğer kuruluşları da olumsuz etkileyerek geniş anlamda finansal kayıp ve batıklara yol açan risk olarak ifade edilebilir. 2007 - 2009 yıllarında yaşanan son finansal kriz ile birlikte sistemik risk, sistemik riskin ölçülmesi ve yönetilmesi finansal kuruluşlar, finans sektörünü düzenleyici yerel ve uluslararası kurumlar ve otoriteler ile birlikte araştırmacılar bakımından önemli konu haline gelmiştir. Sistemik riski ve sistemik riskin belirleyicilerini hesaplamak üzerine yapılan çalışmalarda araştırmacılar bankaların sistemik riske katkısını ölçmeye çalışmışlardır. Esasen bir bankanın bir sistemik riske katkısı, bankanın olası sıkıntı veya batma durumunda karşı karşıya kalacağı finansal kayıp tutarına eşittir. Bu finansal zarar (kayıp) hesaplanırsa, aslında bankanın çözümleme sürecine girdiği anda gereksinimi olan sermaye tutarı hesaplanmış olur. Sistemik risk ve riske maruz değer kavramları üzerinde yoğunlaşan bazı çalışmalar hakkında kısaca özet bilgiler da aşağıda yer verilmektedir:

Adrian \& Brunnermeier (2016) çalışmalarında risk yönetim modellerini temel alan CoVaR yöntemini finansal sektörün riske maruz değerinin (Value-at-Risk), bir finansal kuruluşun sıkıntıya düşmesi halinde ya da her şeyin normal seyri durumunda bu kuruluşun hesaplanan riske maruz değerine koşullu olarak tahmin edilmesi olarak tanımlamıştır.

CoVaR kısaca bir finansal kuruluşun krizde olması durumunda finansal sistemin maruz kalacağı risk olarak tanımlanmaktadır. Bir finansal kurumun sistemik riske katkısı $\Delta$ CoVaR ile gösterilmekte ve kurum kriz durumunda iken finansal sistemin hesaplanan CoVaR'ı ile normal durumdaki bir başka deyişle medyan konumunda finansal sistemin hesaplanan CoVaR'ı arasındaki fark olarak tanımlanmaktadır. $\Delta$ CoVar'ı yüksek olanın sistemik riske katkısı da büyüktür. CoVaR yöntemine getirilen en büyük eleştiri finansal kuruluşların varlıklarının piyasa değerine ihtiyaç duyulduğundan, bu yöntemin yalnızca halka açık kuruluşlara uygulanabilmesidir.

Adrian \& Brunnermeier (2016) çalışmalarında sonuç olarak; finansal krizler veya finansal aracılık sıkıntısı yaşanan dönemlerde, finansal sıkıntının finansal kurumlar arasında yayılma eğiliminde olduğunu ve bu tür yayılmalardan önce bir risk oluşturma aşamasının geldiğini ve her iki unsurun da finansal sistemin riskine önemli katkıda bulunduğunu belirtmişlerdir. $\Delta \mathrm{coVaR}^{\prime} ı$, bireysel finansal kurumlar için tasarlanmış önlemleri tamamlayan, sistemik riskin bir ölçüsü olduğunu, ayrıca $\Delta$ coVaR'ın, makro ihtiyati bir bakış açısı sağlamak için risk ölçümünü genişlettiğinden bahisle ileri- $\Delta \operatorname{coVaR}^{\prime} ı n$, sistemik risk katkısının ileriye dönük 
bir ölçüsü olduğunu ileri sürmüşler ve potansiyel olarak makroihtiyati politika uygulamalarında kullanılabileceğini öne sürmüşlerdir.

Civan (2018) çalışmasında; sistemik risk konusunu Türkiye'de faaliyet gösteren bankalar açısından incelemiş, Türkiye'de faaliyet gösteren bankaları koşullu riske maruz değer yöntemi kullanarak sistemik risk açısından analiz etmiştir.

Çalışmada, Tobias Adrian ve Markus Brunnermeier'in 2011 yılında yayımlanan makalesi ve en son 2014 yılında revize edilen makalesindeki yöntem ve modeller temel alınmıştır

Türkiye'de faaliyet gösteren bankalar ve bunların bağlı kuruluş ve iştirakleri finansal sektörün neredeyse tamamını oluşturduğundan bahisle, çalışmada sadece bankacılık sektörü dikkate alınmıştır. 2005-2016 dönemine ilişkin Türk finansal sektörünün aktif büyüklüğün yaklaşık \%87'lik kısmının 13 büyük banka tarafından oluştuğundan hareketle 13 bankayı ( T.C. Ziraat Bankası A.Ş., T. Halk Bankası A.Ş., T. Vakıflar Bankası T.A.O., T. İş Bankası A.Ş., Akbank T.A.Ş., T. Garanti Bankası A.Ş., Yapı ve Kredi Bankası A.Ş., Denizbank A.Ş., Finansbank A.Ş., T. Ekonomi Bankası A.Ş., Şekerbank A.Ş., T. Sınai Kalkınma Bankası A.Ş., T. Kalkınma Bankası A.Ş. kapsayacak bir analizin Türk bankacılık sektörünün taşıdığı sistemik risk ve özellikleri hakkında fikir verecek bir çalışma olacağı öngörülmüştür.

Yapılan çalışmanın bütününe bakıldığında, bankaların münferit riskini ölçen VaR ile bulaşma ve iç içe geçmişlik riskini ölçen CoVaR karşılaştırılması yapıldığında, en yüksek VaR değerine sahip olan bankanın aynı şekilde en yüksek CoVaR değerine sahip olmadığı, hatta en düşük $\mathrm{CoVaR}$ değerini bile taşıdığı görülmüştür. Yapılan tahminlerin sonucunda en büyük aktif büyüklüğüne sahip bankaların taşıdığ 1 sistemik riskin daha fazla olduğu sonucuna ulaşılmıştır. Analiz sonucunda bir finansal kriz durumunda bu bankaların finansal sistemin taşıdığı riski önemli oranda artırabileceği tahmin edilmiştir.

Saçcı (2014) ise çalışmasında; Basel Komite tarafından D-SIB'lar (Domestic Systemically Important Banks = Yerel olarak sistematik bakımdan önemli olan bankalar) için yayımlanan ilkeler çerçevesinde, G-SIB yöntemi de dikkate alınarak, Türk Bankacılık Sektörü'nde faaliyet gösteren D-SIB'ları belirlenmeye çalışmıştır. Çalışmada D-SIB'ların belirlenmesinde, gösterge bazlı bir yöntem kullanılarak bankaların sistemik önem dereceleri hesaplanmış ve bankalar, kümeleme analizi yardımıyla sistemik önem derecelerine göre gruplandırılmış ve bu yolla Türk bankacllık sektöründe faaliyet gösteren D-SIB'lar tespit edilmiştir.

Li (2018) ise çalışmasında. z-skoruna odaklanarak hem bireysel banka riski hem de sistemik risk olmak üzere banka riskini ölçmeyi hedeflemiştir. Z-skoru, bireysel banka riskinin popüler bir göstergesi olarak ele alınmaktadır. Bu araştırmada, zamanla değişen z-skoru ölçümünün oluşturulmasına yönelik mevcut yaklaşımlardaki başlıca zorlukları tartışmakta olup, üç aylık verileri kullanarak bu yaklaşımları Yeni Zelanda bankaları üzerinden ampirik olarak karşılaştırılmıştır. Çalışmada risk ağırlıklı bir z-skoru ölçüsü önerilmektedir.

Çalışmada öncelikle zamanla değişen z-skoru oluşturmaya yönelik yaklaşımlar çerçevesinde Yeni Zelanda ve Avustralya bankacılık piyasalarına ampirik olarak farklı yaklaşımlar uygulanmıştır. Buradaki amaç, z-skorundaki öğelerin doğru ölçümü, farklı yaklaşımların mantığı ve z-skorunun bazı uzantıları ile ilgili olarak zamanla değişen z-skoru ölçüsünü oluşturmak için daha anlamlı bir yaklaşım bulmak ve ayrıca, banka risklerinin değerlendirilmesinde z-skorunu bir dizi başka risk ölçüsü ile karşılaştırmaktır. 
Çalışmada z-skoru, Yeni Zelanda bankaları için özkaynak/varlık oranı, takipteki alacakların toplam aktiflere oranı ve risk ağırlıklı aktiflerin toplam varlıklara oranı gibi muhasebe tabanlı risk ölçütleri ile karşılaştırılmıştır. Çalışmada, z-skoru ölçümünde kullanılan öz sermaye-varlık oranının analizi, daha fazla sermayeye sahip bankaların daha yüksek bir zskoru değerine sahip olduğunu, bunun da daha düşük banka riski anlamına geldiğini göstermiştir. Bu da, özellikle sistemik önemli büyük bankalar için denetim otoritelerinin ilave sermaye tamponu gerekliliği ile tutarlı bir yaklaşımdır. Bu araştırma ayrıca, bir bankanın sistemik riske marjinal katkısını değerlendiren z-skoruna dayalı yeni bir sistemik risk ölçüsü önermektedir.

Literatür taramasının da ortaya çıkardığı üzere sistemik riskin ölçülmesinde kullanılan tek ve standart bir yöntem bulunmamaktadır. İlgili literatürde farklı yaklaşımlarla bu riskin ölçüldüğ̈̈ görülmektedir. Esasen sistemik risk ölçülürken riske maruz değer hesaplamaları yapılmaktadır ve banka riske maruz değer hesaplaması da bankaların çözümleme maliyetinin hesaplanmasında kullanılabilecek bir yaklaşımdır.

\section{3. ÇALIŞMANIN YÖNTEMI}

\subsection{Merton Modeli}

Türk Bankacıllk Sektöründe çözümlemenin maliyetini belirlemek için Grimaldi \& Linder (2018) in çalışmalarına kullandığı Merton modeline dayanan Şarta Bağlı Alacak Analizi (Contingent Claim Analysis) kullanılmıştır. Merton modeli bankanın borca batıklık durumu için teorik bir temel sağlayan yapısal yaklaşım temelli bir modeldir. Söz konusu model ileriye dönük (piyasa tabanlı) ve bilanço bilgilerinin bir kombinasyonuna dayanmaktadır. Temel model, hissedarların sınırlı yükümlülüğü göz önüne alındığında, temel varlık değeri üzerinde bir alım opsiyonu olarak banka öz sermayesini değerlendirmek için standart Black\&-Scholes opsiyon fiyatlandırma teorisini kullanır. Banka yükümlülüklerinin belli bir seviye gelmesini tehlike eşiği olarak almaktadır.

Black-Scholes opsiyon fiyatlama teorisi yaklaşımı kullanılarak firmaların temerrüt riski hakkında hesaplamalar yapılabilmektedir. Dolayısıyla bu yöntemler yeterli miktarda temerrüt verisinin var olmadığı ve dolayısıyla istatistiki yöntemlerden faydalanmanın mümkün olmadığı durumlarda kullanılabilmektedir. Ancak opsiyon fiyatlama modelleri firmanın borç ve sermayesine ilişkin piyasa verilerine ve özellikle de bunların volatilitesine ihtiyaç duymaktadır. Opsiyon fiyatlama modelleri yaklaşımı; bir firmanın toplam varlık değerinin, toplam borç değerinin altına düşmesi halinde borca batıklık durumu oluşması fikrine dayanmaktadır.

Bir firmanın sermayesinde sahip olunan payın o firmaya ait varlıklar üzerinde en son sırada hak iddia etmeye izin verdiği ve aynı zamanda da kısıtlı şekilde sorumluluğa sebep olduğu bilinmektedir. Merton (1974) bu durumun aslında bir firmaya ait hisse senedinin o firmanin varlıkları üzerinde sahip olunan bir alım (call) opsiyonuna eşit olduğunu fark etmiş ve bu eşitliği kullanarak bir firmanın varlıklarının piyasa değerinin ve volatilitesinin nasıl hesaplanabileceğini ortaya koymuştur. Merton; Black \& Scholes (1973) tarafından geliştirilmiş olan opsiyon fiyatlama yaklaşımından faydalanarak bir firmanın varlıklarının piyasa değerini ve volatilitesini o firmanın hisse senedi üzerine yazılmış olan opsiyonların fiyat ve volatilitelerini kullanarak hesaplama imkanı sağlayan bir yaklaşım ortaya 
koymuştur. Bu yaklaşımla hesaplanan varlık değeri ve volatilitesi birleştirilerek distance to default (temerrüde olan uzaklık) adlı bir kredibilite ölçümü yapılabilir hale gelmiştir. Esasen distance to default firmanın temerrüt noktasından kaç standart sapma uzakta olduğunu gösteren bir ölçüttür ve küçük değerler firmanın temerrüde düşme olasılığının fazla olduğu anlamina gelecektir.

Opsiyon fiyatlama modelinin işletme finansmanında çeşitli uygulamaları mevcuttur. Black \& Scholes 1973 yılındaki makalelerinde kaldıraçla finanse edilen bir şirketin özkaynağının, firma değeri üzerine bir alım opsiyonu olduğuna dikkat çekmişlerdir. Daha sonraki yıllarda yayımlanan makalelerde de opsiyon fiyatlama modelinin değişik işletme finansmanı konularına nasıl uygulanabileceğine ilişkin yöntemler geliştirilmiştir. Modele göre, bir banka veya şirket, sıfır kuponlu tahvillerin ${ }^{1}$ borcunu geri ödeyemediği durumda temerrüde düşmüş bir başka ifade ile borca batık sayılmaktadır. Merton Modeline göre, borca batıklık; bir şirketin varlıklarının değeri, gelecekteki ödemekle yükümlü tahvillerin değerinden düşük olduğunda ortaya çıkar. Bir başka ifade ile bir şirket veya banka, tahvil sahiplerine borçlu olduğu tutarın varlıklarının değerinden yüksek olması durumunda, borca batıklık durumu gerçekleşmiş demektir.

Modele göre bankanın batıklık durumu riski ile sermaye yapısı arasında açık bir ilişki olduğu varsayılmaktadır. (Grimaldi \& Linder, 2018). Bu nedenle aşağıdaki denklemde sermaye yapısı temel denge ilişkisi ile verilmektedir;

$A_{t}=E_{t}+D_{t}$

Bankanın varlığ1 $(A t)$ özkaynak $(E t)$ ile finanse edilmiştir ve $\mathrm{T}>t$ zamanında vadesi dolan nominal tutar borcun $(F)$ t zamanındaki tutarı $(D t)^{\prime}$ dir.

$A_{T}>F$ olduğunda, bankanın alacaklılarının tüm tutarı $(F)$ karşılanabilir ve özkaynak değeri hala $A_{T}-F$ olur. Öte yandan, banka $T$ zamanında $A_{T}<F$ durumunda sıkıntıya girmiş olduğunda, bu durumda alacaklılar kalan varlıklarla ilgili ilk hak talebine sahip olmakta ve hissedarlara herhangi bir tutar kalmamaktadır. Burada, varlık volalitesinin, $\sigma A$, modelin en basit versiyonunda zaman süresince sabit olduğu varsayılmaktadır.

Bir başka ifade ile özsermaye, $E t$, borç sahiplerine ödendikten sonra varlıklar üzerinde kalan bir talep olarak tanımlandığından (Denklem 1), firmanın kalan borç tutarı D'ye eşit bir uygulama fiyatı ile firmanın varlıkları üzerinde zımni bir alım opsiyonu olarak görülebilir. Fikir şu ana varsayımdan kaynaklanmaktadır. Borç sahipleri, özkaynak sahiplerine bir satım opsiyonu sözleşmesi önerecek olsalardı, alacaklıların varlıklar ile temerrütsüz borç değeri arasındaki farkı ödeme yükümlülüğü bulunduğundan, bu noktada finansal başarısızlı̆̆ı gösteren bir eşik veya engel vardır. Bu eşik, o satım opsiyonunun kullanım fiyatı olacaktır. Dolayısıyla, varlık fiyatının belirtilen fiyat seviyesinin altına düşmesi durumunda, alacaklılardan özkaynak sahibine bir ödeme yapılacaktır.

\footnotetext{
${ }^{1}$ Burada sıfır kuponlu tahvillerden kastedilen bankanın borçlarının tahvil olarak olması durumunda herhangi bir kupon ödemesinin olmamasıdır. Bu durum modelin hesaplamasını basitleştirmek için genellikle fianans literatüründeki modellerde uygulanan bir yaklaşımdır. Aksi takdirde kupon ödemeli borç tahvilleri olması durumunda analizi yapmak sıkıntılı olacaktır. Çünkü yalnızca, sıfır kuponlu tahvillerde vade (maturity) ve efektif vade (duration) birbirlerine eşittir. Kupon (faiz) ödemesi varsa efektif vade, vadeden kısadır.
} 
Standart Black - Scholes opsiyon fiyatlandırma formülünün (Black ve Scholes (1973)) uygulanması, öz sermaye için iyi bilinen kapalı form ifadesini şu şekilde vermektedir:

$$
\begin{aligned}
& E_{t}=A_{t} N\left(d_{1}\right)-F e-r\left({ }^{T-t)} N\left(d_{2}\right)\right. \\
& \text { r: risksiz faiz oranı ve }
\end{aligned}
$$

$N(*)$ : aşağıdaki $\mathrm{d}_{1}$ ve $\mathrm{d}_{2}$ değerlerinin normal kümülatif dağılım fonksiyonudur.

$$
\begin{aligned}
& \mathrm{d} 1=\sqrt{\frac{\ln \left(A_{t}\right)+\left(r+\frac{\sigma A^{2}}{2}\right)(T-t)}{\sigma A \sqrt{ }(T-t)}} \\
& \mathrm{d}_{2}=\mathrm{d}_{1}-\sigma \mathrm{A} \sqrt{ }(\mathrm{T}-\mathrm{t})
\end{aligned}
$$

Alacaklılar temerrüt riskine maruz kalmakta, ancak dayanak varlığın kullanım fiyatı $F$ ile yazılan bir Avrupa satım opsiyonunu satın alarak pozisyonlarını korumaya alabilirler. Satım seçeneği $A_{T}<F$ ise $F-A_{T}$ değerinde ve $A_{T}>F$ olduğu durumda ise değersiz olacaktır. Bu nedenle, $\mathrm{T}$ vadesindeki riskli borç, risksiz tahvil eksi dayanak varlık üzerine yazılmış bir Avrupa satım opsiyonunun getirisi $\left(\max \left(F-A_{T}, 0\right)\right)$ olarak ifade edilebilir:

$D_{T}=\mathrm{F}-\max \left(F-A_{T}, 0\right)$

Bir satım opsiyonunun, $\mathrm{t}$ zamanındaki fiyatı, Avrupa satış opsiyonu için Black-Scholes formülü uygulanarak şöyle belirlenebilir:

$P_{t}=F e^{-r(T-t)} \mathrm{N}\left(-d_{2}\right)-A_{t} \mathrm{~N}\left(-d_{1}\right)$

$\mathrm{Bu}$ noktada, firmanın fonlama yapısının basit bir şekilde sadece tek çeşit borç ve hisse senetlerinden oluştuğu varsayılmıştır. Firmanın bütün borcunun vadesinin T anında dolması beklenmektedir. Buna ilaveten sermaye ve varlık volatilitelerinin aşağıdaki şekilde ilişkili oldukları gösterilebilir:

$$
\sigma E=\frac{A_{t} \partial E_{t}}{E_{t} \partial A_{t}} \sigma \mathrm{A}(\mathrm{T}-\mathrm{t}) \quad \text { (özkaynak volalitesi) }
$$

Özkaynak ve özkaynak volalitesi için olan denklemler kullanıldığında varlık değeri $A$ ve oynaklığ $\sigma_{A}$ elde edilebilir. $A$ ve $\sigma_{A}$ için sayısal çözümler bulunduğunda, her bir banka için temerrüt etmeye olan mesafeyi şu şekilde hesaplamak mümkündür:

$$
D D t=\frac{\ln \left(\frac{A(t)}{F}\right)+\left(\mu+\frac{1}{2} \sigma_{A}^{2}\right)(\tilde{T}-t)}{\sigma_{A} \sqrt{\tilde{T}-t}}
$$

Burada $\mu$ varlıkların volalitesini göstermektedir.

Finansal sıkıntıya ${ }^{2}$ olan mesafe, finansal sıkıntı bir başka ifade ile borçların toplam değerinden uzaklığını gösteren bankanın varlığının değerinin standart sapmalarının sayısı

\footnotetext{
${ }^{2}$ Burada finansal sıkıntı kavramının kullanılmasının nedeni esasen yabancı kaynaklarda financial distress kavramının kullanılmasından kaynaklanmaktadır. Çalışmanın geneline bakıldığında ise finansal sıkıntıyla kastedilen borca batıklık veya temerrüde düşme durumudur. Bu nedenle, çalışmamızın geneinde finansal sıkıntı kavramı borca batıklık durumu ile aynı anlama gelmektedir.
} 
olarak yorumlanabilir. $\mathrm{Bu}$ nedenle, varlıkların piyasa değerinin zaman boyunca yükümlülüklerden daha düşük olma olasılığının bir ölçüsü olarak da kullanılabilir.

Finansal sıkıntıya olan mesafe $\left(D D_{t}\right)$ hesaplandıktan sonra, finansal sıkıntı olasılığ $(P D)$, önceden tahmin edilen çözümleme maliyeti (ex-ante resolution cost) ve sonradan oluşan çözümleme maliyeti (ex-post resolution cost) aşağıdaki gibi hesaplanabilir ;

Probability of distress $t=N\left(-D D_{t}\right)$

$$
\begin{aligned}
& \text { Ex-post resolution cost } t=1-\left(\frac{\ln \left(A_{t}\right)+\left\{r+\frac{\sigma A^{2}}{2}\right)(T-t)}{\sigma A \sqrt{T-t}}\right)\left(\frac{A t}{F e^{-r(T-t)}}\right)\left(F e^{-r(T-t)}\right) \\
& \text { Ex-ante resolution cost } t=F e^{-r t} N\left(-D D_{t}+\sigma A \sqrt{T-t}\right)-A(t) N\left(-D D_{t}\right)
\end{aligned}
$$

Burada belirli bir vade $\mathrm{T}$ için ex-ante cost, esasen uygulama fiyatı F'ye eşit olan, bankanın varlıkları (A) üzerindeki bir satım opsiyonunun değerine eşittir. Çünkü bu fiyat bankanın alacaklıların zarara başabaş noktasında katlanacakları fiyatı göstermektedir.

Grimaldi ve Linder (2018) çalışmalarında, modelde kullanacakları banka risklilik değişkenlerini iflas olasılığı, önceden tahmin edilen maliyet ve ortaya çıkan maliyet olarak belirlemişler ve aşağıdaki şekilde yorumlamışlardır. Bu genel olarak da Merton modelini uygulandığ çalışmalardaki sistematiğe paraleldir.

İflas Olasılı̆̆ı (PD)

Banka riskinin önemli bir bileşeni, borca batıklık durumunda meydana gelen kayıp (sermaye açığı) değil, aynı zamanda bu tür bir sıkıntının ortaya çıkma olasılığıdır. Model varsayımlarına göre, banka varlıklarının değeri, borçların değerinden daha düşük olduğunda borca batıklık durumu ortaya çıkmaktadır. Dolayısıyla, borca batıklık durumu olasılığı, bankanın değerinin vade sonunda borcunun nominal değerinden daha az olma olasılığıdır.

\section{Sikıntı Sonucu ortaya çıkacak maliyet (ex post cost)}

Bir banka hissedarının bakış açısına göre, bankanın borca batık olduğu göz önüne alındığında, bankanın maruz kaldığı zarar, banka sonrasındaki çözüm maliyetidir ve bu nedenle, borca batık olan bir bankayı çözmenin maliyetinin bir ölçüsüdür. Bir başka deyişle, borca batık duruma düşen bir bankayı yeniden çözüme kavuşturduğu noktaya, bir başka ifade ile varlığının piyasa değerinin en azından borçlarının piyasa değerine eşit olduğu bir noktaya döndürmek için gereken maliyettir. Çoğunlukla, sonradan çözüm maliyeti, bir bankanın kurtarma veya kurtarma yoluyla çözülmesine bakılmaksızın aynıdır. İflasa girmiş bir banka bir kurtarma yoluyla çözümlenirse, harcama sonrası çözüm maliyetleri, borcun kefaletle ödenen borç karşılığında alınabilecek veya öz sermayeye dönüştürülebilen kısmına karşılık gelmektedir. Burada otofinansman sistemi devreye girmektedir.

Banka özkaynakları tarafından karşılanan zararlarla birlikte ele alındığında, harcama sonrası çözüm maliyetlerinin, özkaynak ve özellikli borçlar için asgari gerekliliğin bir parçası olarak çözümleme otoritesi tarafından belirlenen zarar karşılama tutarına (LLA = Loan Loss Allowance) tam olarak karşılık gelemeyeceğine dikkat etmek önemlidir. Bir banka bunun yerine kurtarma yoluyla çözülürse, çözüm maliyetleri, otoriteler tarafından enjekte edilen 
veya garanti edilen özkaynak tutarından kalan özsermayenin gerçeğe uygun değerinin çıkarılması ile belirlenen tutara karşılık gelmektedir.

\section{Önceden tahmin edilen maliyet}

Önceden tahmin edilen çözüm maliyeti, tehlikede olan bir bankayı çözmenin maliyetidir ve söz konusu sıkıntının meydana gelme olasılığı ile ağırlıklandırılmaktadır. Bu nedenle, ön çözüm maliyetleri, tehlike olasılığ edilmektedir. Banka riski göstergesi olarak, önceden tahmin edilen maliyet, sonradan ortaya çıkan ödeme maliyetinden daha iyi bir ölçüdür çünkü aynı zamanda kriz dönemlerinin dışındaki olasılık ağırlıklı riski de yakalar. O nedenle, Grimaldi ve Linder (2018) analizlerinde ön çözüm maliyetinin hesaplanmasına odaklanmaktadır. Ön çözümleme maliyetini hesaplamak için üç temel girdi olarak, hisselerin piyasa değeri, borç tutarı ve öz sermaye değişkenliğini kullanmışlardır. Bu, ön çözüm maliyetlerinin bu değişkenlerin her birindeki değişikliklerden veya bunların bir kombinasyonundan etkilendiği anlamına gelmektedir. Genel olarak, ön çözüm maliyetlerinin daha yüksek bir değeri, ya yüksek düzeyde bir finansal kaldıraçla, bir başka deyişle borcuyla varlıklar arasındaki oranla ya da yüksek düzeyde öz sermaye oynaklığıyla veya her ikisiyle ilişkilidir.

\subsection{Ampirik Uygulama}

Bir banka, varlıkları yükümlülüklerini karşılayamadığında ödeyebilirlik ve dolayısıyla yükümlülüklerini yerine getirememe problemi ile karşılaşmaktadır. Bu durumda genel olarak dünyadaki uygulamalara bakıldığında, finansal sistemde denetim ve gözetimden sorumlu otoriteler, sektörün fonksiyonlarının sağlıklı ve güvenli bir biçimde sürdürülmesini teminen bankalara bir çözümleme süreci uygulayabilmektedir. Bazı şartlar altında, denetleyici otorite, bir yeniden yapılandırma programı ortaya koyarak, bankanın mevcut ortakları ve yöneticileriyle faaliyetlerine devam etmesini de öngörebilmektedir. $\mathrm{Bu}$ alternatiflerin yanı sıra, sıklıkla görüldügü üzere, denetleyici otorite, bankanın kapatılmasına karar vermekte ve bankacılık lisansını iptal etmektedir. Ancak öncelikle sistem içinde çözüm çalışmalarının yapılması ve bankanın sistemden çıkarılmasının son yöntem olarak düşünülmesi gerekmektedir. Tabi bu arada uygulanacak çözümleme rejimi sonucunda oluşacak maliyet devreye girmektedir. Çok yüksek bir çözümleme maliyetinin öngörüldüğü durumlarda bankaları çözümlemek yerine tasfiyesini istemek daha uygun olabilmektedir.

Bununla birlikte, 2009 finansal krizinden sonra çözümleme konusunda yeni bir yaklaşım gelmiş ve çözümleme süreci bankalar henüz iflas noktasına gelmeden işletilmeye başlayan bir süreç olarak finansal literatüre ve uygulamalara girmiştir. Bir başka deyişle, çalışmamızda da anlatıldığı üzere çözümleme kavramı ve anlayışı son on yıldır ciddi bir değişim geçirmiştir.

Global bazda finansal krizler, dönem dönem görüldüğünden dünyada finansal krizlerin etkileri üzerine yapılan çok sayıda çalışma bulunmaktadır. Özellikle son dönemde yapılan çalışmalarda, 2008 yılındaki finansal kriz sonrası çok tartışılmaya başlanan finansal sistemin taşıdığı riskin ve finansal kuruluşların bu riske katkısının ölçülmesine de ağırlık verilmiştir. $\mathrm{Bu}$ alandaki çalışmalar özellikle "batmayacak kadar büyük" kavramından da hareketle sistemik risk taşıyan bankalar ve bu bankaların riske maruz değerleri üzerinden yapılmaktadır. Doğrudan çözümleme maliyeti hesaplamasına ilişkin yapılan çalışmalar ise 
çok fazla sayıda değildir. Bu nedenle literatür taraması yapılırken bankaların veya bankacılık sektörünün çözümleme maliyetine ilişkin çalışmaların yanısıra sistemik riskin belirlenmesi ve bankaların sistemik riske katkısını hesaplamaya yönelik çalışmalar da taranmıştır. Bankaların sistemik riske olan katkısı hesaplanırken, bu hesaplamanin bir anlamda bu bankaların herhangi bir kriz veya batma durumunda ne kadarlık bir kayıp yaşayacağı ve bu bankaların çözümleme kapsamı durumuna girmesi durumunda ne kadar bir maliyete neden olacağı konusunda da bir gösterge olduğu düşünülmektedir.

$\mathrm{Bu}$ anlamda bakıldığında, çözümleme rejiminde alınacak ön tedbirler ve uygulamalar ilerideki kriz durumunda ortaya çıkabilecek çözümleme süreçlerinin en az maliyetli bir şekilde tamamlanmasına yöneliktir ve bu yaklaşımla $\mathrm{AB}$ başta olmak üzere diğer ülkelerdeki denetim ve gözetim otoriteleri kendi ön tedbirlerini almaya ve bu yönde düzenlemelere başlamışlardır. Bu noktada da kanımızca çözümleme maliyetlerinin önceden tahmin edilebilmesi ve bu maliyetlerini etkileyen değişkenlerin belirlenmesi otoritelerin uygulamaya koyacağ

Çalışmanın bu bölümünde, uluslararası alanda yapılan çalışmalara paralel olarak, Türk Bankacılık Sektörü'nde olası çözümleme maliyetinin bir başka deyişle bankaların borca batık duruma düştüğünde gerekecek sermaye gerekliliğinin tahmin edilmesi hedeflenmektedir.

Literatürde çözümleme maliyetinin hesaplanmasına ilişkin çok fazla sayıda çalışma bulunmamaktadir.

\subsection{Araştırmada Kullanılan Veri Seti ve Kaynaklar}

Yapılan uygulamada Grimaldi ve Linder (2018) in çözümleme maliyetini hesaplamak için kullandığ1 Merton modeline dayanan Şarta Bağlı Alacak Analizi (CCA) yöntemi baz alınmıştır.

Merton modeli, bankanın temerrüde düşmesi durumunun tespiti için teorik bir bakış açısı sağlayan yapısal yaklaşım temelli bir modeldir. İleriye dönük (piyasa tabanlı) ve bilanço bilgilerinin bir kombinasyonuna dayanmaktadır. Temel model, hissedarların sinırlı yükümlülügü göz önüne alındığında, temel varlık değeri üzerinde bir alım opsiyonu olarak banka öz sermayesini değerlendirmek için standart Black-Scholes opsiyon fiyatlandırma teorisini kullanır. Banka yükümlülüklerinin belli bir seviye gelmesini tehlike eşiği olarak almaktadir.

Çalışmada çözümleme maliyetinin hesaplanması için Bankaların 2004-2019 dönemlerinde kamuya açıklanan yılsonu bilanço verileri kullanılmıştır. Veriler, Türkiye Bankalar Birliği'nin internet sayfasından ve bankaların kamuya açı olarak yayımlanan bağımsız denetim raporlarından derlenmiştir. $\mathrm{Bu}$ analiz yapılırken çalışmamızın daha önceki bölümlerinde de belirtildiği üzere uluslararası düzenlemeler ışığında yeni çözümleme rejimlerinin özellikle sistemik öneme haiz bankalar için hayata geçirildiği ve/veya geçirilmesi öngörüldüğ̈̈nden Türkiye'de sistemik öneme haiz olarak görülebilecek 12 bankanın verileri kullanılmıştır. Bu bankalar aşağıdaki tabloda yer almaktadır:

\section{Tablo 1}

T.C. Ziraat Bankası A.Ş 


\begin{tabular}{|l|}
\hline T. Halk Bankası A.Ş. \\
\hline T. Vakıflar Bankası T.A.O. \\
\hline T. İş Bankası A.Ş. \\
\hline 00Akbank T.A.Ş. \\
\hline T. Garanti Bankası A.Ş. \\
\hline Yapı ve Kredi Bankası A.Ş. \\
\hline Denizbank A.Ş. \\
\hline QNB Finansbank A.Ş. \\
\hline BNP Paribas T. Ekonomi Bankası A.Ş. \\
\hline ING Bank A.Ş. \\
\hline HSBC Bank A.Ş \\
\hline
\end{tabular}

\section{4. Çözümleme Maliyetlerinin Hesaplanması}

Çözümleme maliyeti hesaplanırken Grimaldi ve Linder (2018) in çalışmalarında kullandıkları yöntem paralelinde veriler hazırlanırken söz konusu 12 bankanın aktif değeri, borç tutarı ve öz sermaye tutarları temel girdiler olarak kullanılmış ve banka bazında çözümleme maliyetleri hesaplanmıştır. Sektörün çözümleme maliyeti olarak da bu hesaplanan çözümleme maliyetlerinin toplamı alınmıştır. Sektörde yer alan küçük bankaların analize dahil edilmemesinin sebebi bu bankaların bilanço yapılarının daha farklı olması ve analizde daha farklı sonuçlara yol açabilme durumudur. Ayrıca, global anlamda çözümleme konusunun genellikle SIFI'ler D-SIB'ler için uygulanması hususunda, çalışmamızın daha önceki bölümlerinde de belirttiğimiz üzere bir görüş birliği vardır. Ülkemizde de yeni yeni başlayan bankalar tarafından kurtarma ve çözümleme planları hazırlanmasına ilişkin BDDK taslak mevzuatları sektördeki büyük var orta ölçekli bankalar için tasarlanmaktadır. Dolayısıyla bankacılık sektörünün yaklaşık \% 90'ını oluşturan analizimize dâhil ettiğimiz bankalar üzerinden sektörün çözümleme maliyetinin hesaplanmasının sektörün için önemli bir gösterge olacağı düşünülmektedir. Bankaların değişik finansal yapıları dolayısıyla toplam sektör değeri analizde kullanılmıştır.

Esasen finansal sıkıntıya olan mesafe (distance to default) bankanın temerrüt noktasından kaç standart sapma uzakta olduğunu gösteren bir ölçüttür ve küçük değerler bankanın temerrüt etme olasılığının fazla olduğu anlamına gelecektir. Bu teorik yaklaşımı Türk Bankacılık Sektörüne uygulamak için ilgili bankaların yukarıdaki formüllerde yer alan değişken değerlerine ihtiyaç bulunmaktadır. Elde olan veriler neticesinde; banka varlıklarının piyasa değeri yerine defter değerleri kullanılmıştır. Aktif toplamı ve borç toplamı verileri yine TBB veri sisteminden temin edilmiştir. Risksiz faiz oranı ise TCMB veri sisteminden alınmıştır. Modelin uygulanması sırasında ortaya çıkan bir sorun ise formüllerin doğrusal olmayan denklemlerden oluşması sonucu; distance to default hesaplamasının kolay yapılamıyor olmasıdır. Nitekim bu model kullanılarak yapılan ampirik çalışmaların sayısının azlığı da bu problemin varlı̆̆ından kaynaklanmaktadır. Bu çalışma kapsamında 
MS Excel'in "solver" fonksiyonu kullanılarak ve bu fonksiyonu çok kez çalıştırmak için bir makro oluşturularak denklemlerin çözümü sağlanmıştır.

Grimaldi ve Linder (2018)'in çalışmalarında kullanılan hesaplamalar çerçevesinde eşitlik (8) ve (10) Excel'de solver yardımıyla çözülmüş ve önceden tahmin edilen maliyet (exante resolution cost) hesaplaması yapılmıştır. $\mathrm{Bu}$ çerçevede $\mathrm{D}_{\mathrm{t}}$ kuruluşun toplam varlık değerinden özkaynaklarının çıkarılması sonucu bulunan değeri, bir başka ifade ile varlıkların borç ile fonlanan tutarını ifade etmektedir. Diğer taraftan, DDt kuruluşun finansal yapısı uyarınca temerrüde olan uzaklığını bir başka ifadeyle bankanın o dönemdeki risklilik düzeyini ifade ederken $\mathrm{N}(-\mathrm{DD})$ riskin gerçekleşme olasılığını (temerrüt ihtimalini) göstermektedir. Bu kapsamda volatilite ve risklilik düzeyi kullanılarak yapılan hesaplama DDCOST'u verirken buna ilişkin olasılığ $\mathrm{N}$ (DDCOST) ifade etmektedir. Son olarak toplam maliyet risklerin gerçekleşme olasılıkları dikkate alınarak yapılan hesaplama sonucu ortaya çıkmaktadır. Söz konusu gösterge temerrüt durumu oluşmadan çözümleme maliyetini ortaya koyması açısından önem taşımaktadır.

Analizimizde bu hesaplamayı yaparken bankacılık sektörünün aktif büyüklüğü, toplam borç tutarı ve özkaynak büyüklüğü temel girdiler olarak kullanılmıştır. Öte yandan Grimaldi \& Linder (2018) den çalışmasından farklı olarak bankaların özkaynak değeri hesaplanırken hisse senedi verileri yerine bilanço özkaynak verileri kullanılmıştır. Bunun çeşitli sebepleri vardır. Öncelikle analizimize dahil edilen bankaların dolayısıyla da Türk Bankacılık Sisteminin en büyük ölçekli bankası olan Ziraat Bankası, HSBC, ING ve TEB gibi bankaların hisselerinin piyasada işlem görmemesi ve bu durumda Ziraat Bankası başta olmak üzere saydığımız diğer üç bankanın analizde olmamasının hesaplama açısından ciddi etki yaratabileceği düşüncesidir. Diğer bir neden ise, piyasada işlem gören bazı bankaların halka açıklık oranının yüzde 5 seviyelerinde olmasının bir bankanın piyasa değerinin belirlenmesinde yanıltıcı olabileceği düşüncesidir. Bunun yanında BIST endeksinde işlem hacmi darlı̆̆ı ve yüksek volatilite de piyasada oluşan hisse değerlerinin güvenilirliğini etkilemektedir. Bu kapsamda Merton Modelinden elde edilen önceden tahmin edilen çözümleme maliyeti hesaplamasına göre bankacıllk sektörünün çözümleme maliyeti analizimize konu dönemde yıllar bazında aşağıdaki şekilde hesaplanmıştır.

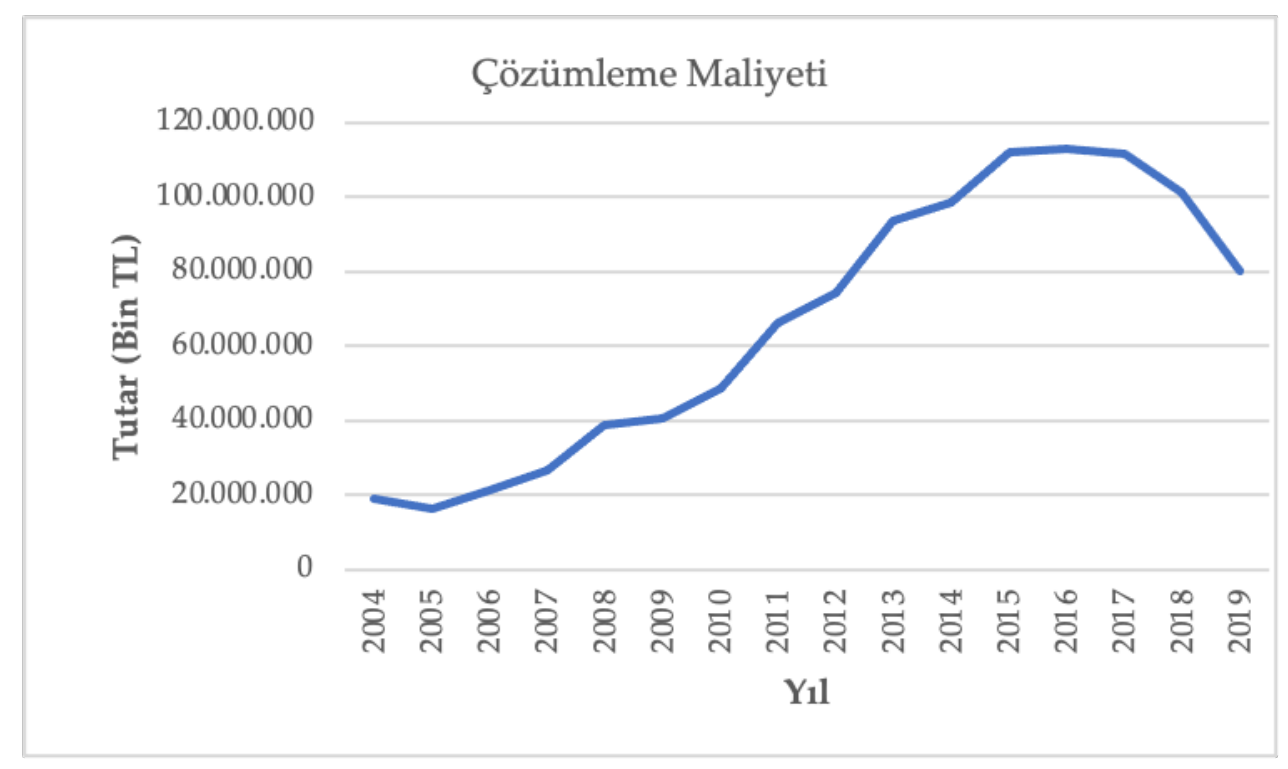




\section{Şekil 1 Merton Modeline Göre Çözümleme Maliyeti}

Yukarıdaki grafiğe bakıldığında bankaların çözümleme maliyetlerinin 2004 yılından 2015 yılına kadar önemli ölçüde artış eğilimi gösterdiği görülmektedir. Bu durumda Türk Bankacılık sektöründe 1999-2002 yılları arasında yaşanan krizden sonra bankaların yeni yeni toparlanma sürecine girmelerinin ve o dönemde düşük karlılık göstergelerinin etkisinin olduğu düşünülmektedir. 2008-2009 yılları arasında yaşanan küresel finansal kriz küresel anlamda bankacılık sektöründe olumsuz etkilere yol açmış dolayısıyla yabancı banka payının yüksek olduğu Türk bankacılık sektöründeki bankalarda da önemli ölçüde sıkıntı yaratmıştır. Bankalar, BDDK'nın sıkı denetim ve gözetimiyle o dönemlerde oldukça ihtiyatlı bir kredi ve özkaynak politikası izlemişler ve küresel krizin etkilerinin yine de sınırlı olmasına çaba gösterilmiştir. Küresel krizden sonra gündeme gelen makro ihtiyati tedbirler politikası kapsamında bankalar güçlü özkaynak yapılarını ve karlılık düzeylerini muhafaza etmişler bu kapsamda da çözümleme için tahmin edilen maliyet kriz döneminden sonra azalmıştır.

Daha sonra 2015'ten sonra dönemde hesaplanan çözümleme maliyetinde bir düşüş eğilimi görülmektedir. Bu dönemde özellikle Basel 3 standartlarına uyum çalışmaları çerçevesinde Bankaların özkaynak ve SYR'lerinin yüksek tutulmasına ilişkin yapılan ilave sermaye tamponları bulundurulması benzeri düzenlemelerin ve bankalarda önemli ölçüde risk yönetimine önem verilmesinin ve risk iştahının sınırlı kalmasının etkili olduğu düşünülmektedir. Ayrıca BDDK tarafından Bankaların kar dağıtımlarının sınırlandırılarak karın bünyede tutulması ve dolayısıyla özkaynakların güçlendirilmesi politikasının da bu dönemde etkili olduğu ifade edilebilir.

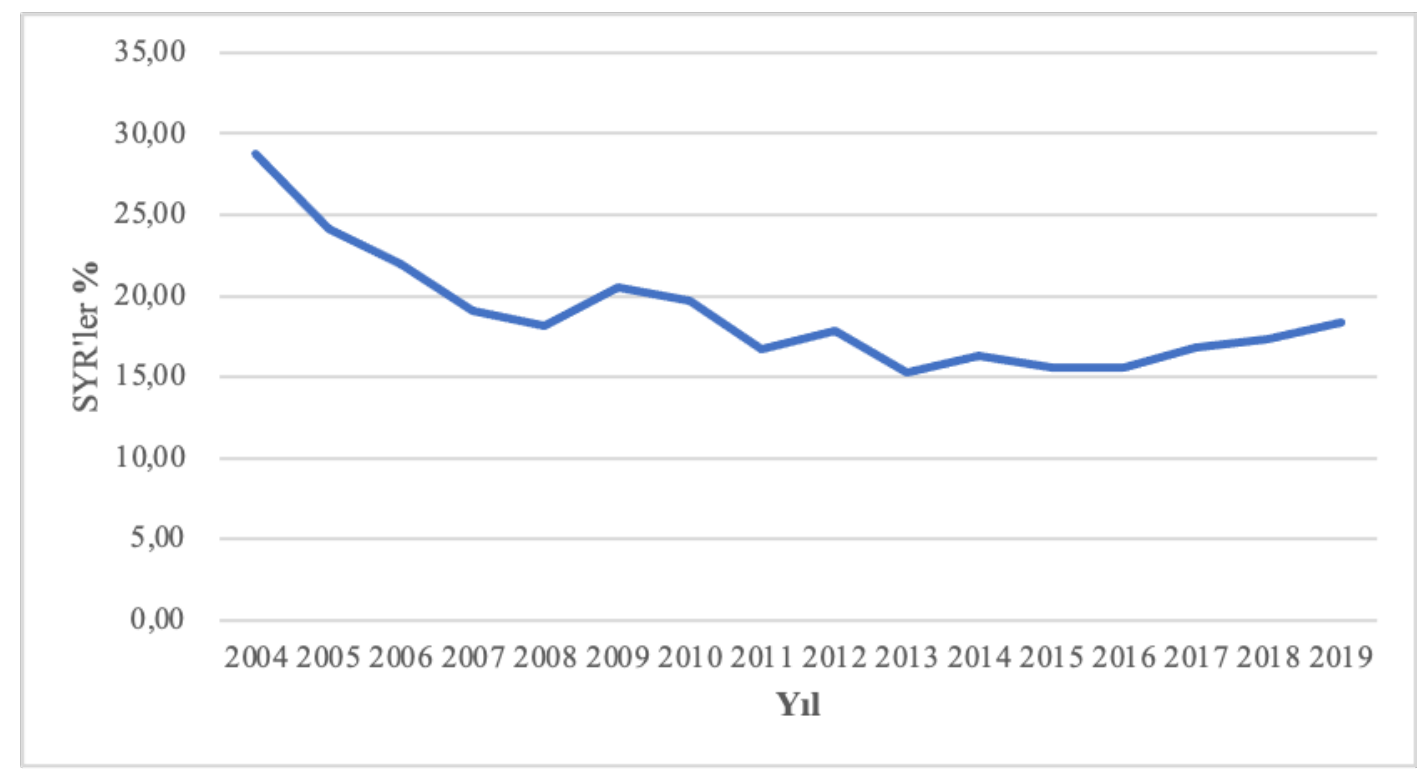

\section{Şekil 2 Türk Bankacılık Sektöründe SYR'nin Gelişimi}

Yukarıdaki grafikte (Şekil 2) verildiği üzere çözümleme maliyetinin önemli ölçüde artış eğiliminde olduğu 2007-2015 yılları arasının ayrıca bankacılık sektörünün sermaye yeterliliğinin en düşük seviyede olduğu dönemler olması da dikkat çekicidir. Bundan sonraki dönemde BDDK'nın banka sermayelerini güçlendirme politikalarının etkileri ve sonrasında Basel Sermaye düzenlemeleri kapsamında özellikle sermaye yeterliliği üzerinde 
alınan tedbirlerden sonra ilave sermaye tamponlarının uygulanmaya başladığı bir dönem mevcuttur. Bu dönemde bankalarda SYR'nin yükseliş trendine girdiği gözlemlenmektedir. $\mathrm{Bu}$ ilave düzenlemeler ve yüksek SYR düzeylerinin ve karlılığın da yükselmesiyle çözümleme için tahmin edilen maliyet azalış trendine girmiş, 2019 yılına kadar bu trendin devam ettiği gözlemlenmiştir. Bu kapsamda SYR nin çözümleme maliyeti üzerinde etkisinin oldukça önemli düzeyde olduğu düşünülmektedir.

Aşağıdaki grafikte (Şekil 3) ise analiz dönemi boyunca ekonomik büyümenin göstergesi olan GSYİH'nın gelişimi verilmiştir.

Çözümleme maliyetinin yükseliş eğiliminde olduğu ciddi bir yükseliş dönemine girdiği 2004-2015 arası dönemde GSYİH büyümesi yavaşlamıştır. Bu durumda GSYİH büyümesinin de çözümleme maliyeti üzerinde etkili olduğu fikrini oluşturmaktadır. GSYİH büyümesinin daha istikrarlı seyrettiği son dönemlerde çözümleme maliyetinde azalış eğilimi görülmektedir.

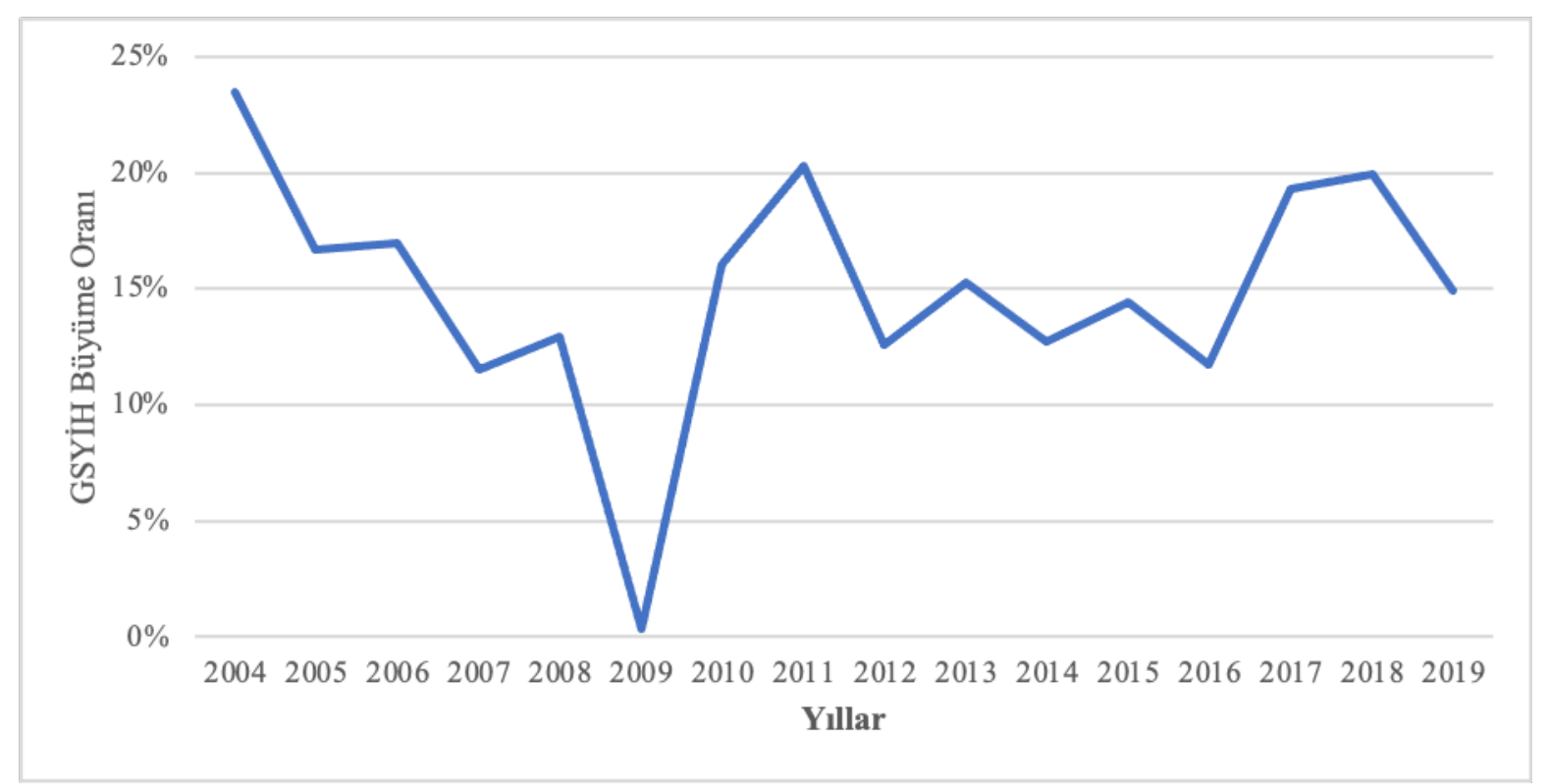

\section{Şekil 3 GSYİH Gelişimi}

\section{SONUÇ VE DEĞERLENDİRME}

Bankacılıkta çözümleme kavramı, borca batık durumda olan ve iflas etmek üzere olan bankaların genellikle kamu otoriteleri tarafından finansal piyasalardaki istikrarı korumak ve bir bankanın sıkıntılarının tüm finansal sisteme yayılmasını önlemek için sahip oldukları yetkilerle bankanın yeniden sağlıklı bir yapıya kavuşturulması veya tasarruf sahipleri ve banka alacaklılarının haklarını belirli ölçüde koruyarak bankayı rehabilite etmesi veya sistemden çıkarması sürecidir. Türk Bankacılık sektörü çözümleme kavramıyla en geniş anlamda 2000'li yıların hemen başında Türkiye' de yaşanan bankacılık krizi ile tanışmıştır.

2007-2009 yılları arasında ABD'de başlayan ve kısa sürede küresel olarak kendini hissettiren finansal kriz başta bankalar olmak üzere birçok finansal kuruluşun iflasına yol açmıştır. Bununla birlikte, küresel finans krizinden sonra Çözümleme konusunda yeni bir yaklaşım gelmiş ve çözümleme süreci bankalar henüz iflas noktasına gelmeden işletilmeye başlayan bir süreç olarak finansal literatüre ve uygulamalara girmiştir. Bir başka deyişle, 
çalışmamızda detaylı olarak incelendiği üzere çözümleme kavramı ve anlayışı son on yıldır ciddi bir değişim geçirmiş, daha proaktif bir yapının kurulması ve çözümlemenin maliyetinin düşürülmesi ve olası karşı karşıya kalınacak maliyetlerin de kamuya dolayısıyla da vergi ödeyenlere yüklenmesinin önüne geçilmesine çalışılmıştır.

$\mathrm{Bu}$ anlamda bakıldığında, çözümleme rejiminde alınacak ön tedbirler ve uygulamalar ilerideki kriz durumunda ortaya çıkabilecek çözümleme süreçlerinin en az maliyetli bir şekilde tamamlanmasına yöneliktir ve bu yaklaşımla $A B$ başta olmak üzere ülkelerdeki denetim ve gözetim otoriteleri kendi ön tedbirlerini almaya ve bu yönde düzenlemelere başlamışlardır. Bu noktada da kanımızca çözümleme maliyetlerinin önceden tahmin edilebilmesi ve bu maliyetlerini etkileyen değişkenlerin belirlenmesi otoritelerin uygulamaya koyacağı çözümleme rejimindeki ön tedbirler açısından oldukça önemlidir.

$\mathrm{Bu}$ kapsamda çalışmamızda da yeni çözümleme rejimi temel özellikleriyle değerlendirildikten sonra Türk bankacılık sektörünün herhangi bir çözümleme süreci ile karşı karşıya kalması durumunda karşı karşıya olunacak sermaye ihtiyacı diğer bir ifade ile çözümleme maliyeti hesaplanması hedeflenmiştir. Bu konuda literatürde yapılan kısıtlı sayıda çalışma olduğundan yapılan bu çalışmalar titizlikle incelenmiş ve uygun bir yöntem olarak görülen Grimaldi ve Linder (2018) in çalışmasında kullandığ1 Merton modeli temel alınmış ve uyarlanmıştır.

Yapılan analiz sonucunda çözümleme maliyetlerinin 2004 yılından 2015 yılına kadar önemli ölçüde artış eğilimi gösterdiği görülmektedir. Bu durumda Türk Bankacılık sektöründe 19992002 yılları arasında yaşanan krizden sonra bankaların yeni yeni toparlanma sürecine girmelerinin ve o dönemde düşük karlılık göstergelerinin etkisinin olduğu düşünülmektedir. 2008-2009 döneminde yaşanan küresel finans krizinden sonra gündeme gelen makro ihtiyati tedbirler politikası kapsamında bankalar güçlü özkaynak yapılarını ve karlılık düzeylerini korumuşlar ve bu kapsamda da çözümleme için tahmin edilen maliyet kriz döneminden sonra bir süre yükseliş eğilimini korumuş ancak daha sonraki dönemlerde azalmıştır. Bu kapsamda, 2015'ten sonra dönemde hesaplanan çözümleme maliyetinde bir düşüş eğilimi görülmektedir. Bu dönemde özellikle Basel 3 standartları çerçevesinde Bankaların özkaynak ve SYR'lerinin yüksek tutulmasına ilişkin yapılan ilave sermaye tamponları bulundurulması ve benzeri düzenlemelerin ve bankalarda önemli ölçüde risk yönetimine önem verilmesinin etkili olduğu düşünülmektedir.

Çalışmanın sonuçları yeni çözümleme rejiminin temel özellikleri ile birlikte ele alındığında, finansal sektörde bu konuda alınan tedbirlerle tutarlı olarak görülmektedir. Güçlü bir sermaye yapısına sahip olan bankaların olası bir kriz durumunda karşı karşıya kalınacak çözümleme maliyetleri daha düşük olacaktır. Bu itibarla, çözümleme konusunda FSB temel özellikler metni ve $A B$ Çözümleme Direktifinde yer alan hususların Türk bankacılık düzenleme ve çözümleri otoriteleri olan BDDK ve TMSF tarafından dikkatle ele alınması ve bu konuda bankacılık mevzuatında gerekli olabilecek değişikliklerin yapılarak bankaların krizlere karşı daha sağlıklı ve güçlü bir finansal yapıya ulaştırılmasının çok önemli olduğu düşünülmektedir. Zira finansal istikrarın korunması ve sürdürülmesi açısından bankacılık sektörü çok önemli bir yerde bulunmakta ve küresel anlamda yaşanabilecek bankacilık krizlerinin sistemik risk etkisi ile her ülkeyi olduğu ülkemiz bankacılık sektörünü de etkilemesi mümkün olabilecektir. 


\section{KAYNAKÇA}

Adrian, T. \& Brunnermeier, M.K. (2016), CoVaR, American economic Review, 106 (7): 170541 ,

Adrian, T. \& Brunnermeier, M.K., (2011), CoVaR, https://www.princeton.edu/ markus/research/papers/CoVaR, 8 Nisan 2016.

Adrian, T. ve Brunnermeier, M.K., (2014), CoVaR, https://www.newyorkfed.org/medialibrary/media/research/staff_reports/sr3.

Avrupa Komisyonu (2014a), Directive 2014/17/EU, Capital Requirements and Regulation Directive.

Avrupa Komisyonu (2014b), Directive 2014/59/EU, Establishing a Framework for the Recovery and Resolution of Credit Institutions.

Basel Committee on Banking Supervision (2011), Global systemically important banks: assessment methodology and the additional loss absorbency requirement.

Basel Committee on Banking Supervision (2012), A Framework for Dealing With Domestic Systemically Important Banks.

Black, F. \& Scholes, M. (1973), The Pricing of Options and Corporate Liabilities, The Journal of Political Economy, Vol. 81, No. 3

Cariboni, J., Langedijk, A. S., Maccaferri, S., Pagano, A. M., Giudici, P., Rancan, M. \& Schich, S. (2016), Reducing and sharing the burden of bank failures, OECD Journal: Financial Market Trends, Volume 2015/2

Civan, Z., (2018), Turkiye'deki Sistemik Öneme Sahip Bankalarm Kantil Regresyon Kullanılarak Koşullu Riske Maruz Değer Yontemi ile Tespit Edilmesi, Doktora Tezi, Yıldız Teknik Üniversitesi Fen Bilimleri Enstitüsü.

FSB (2012), Resolution of Systematically Important Financial Institutios, Progress Report.

FSB (2011), Key Attributes Of Effective Resolution Regimes For Financial Institutions.

Grimaldi, M. B., Hofmeister, J., Schich S. \& Snethlage, D. (2016), Estimating the size and incidence of bank resolution costs for selected banks in OECD countries, OECD Journal: Financial Market Trends Volume 2016/1.

Grimaldi, M. B. \&e Linder, J. (2018), Measuring bank resolution costs - a market-based approach, The Swedish National Debt Office's Focus Report

Li, X. (2018), An Examination of Bank Risk Measures and their Relationship to Systemic Risk Measurement, Doktora Tezi, Massey University, Manawatu (Turitea), Yeni Zelanda

Merton, R. (1974), On The Pricing Of Corporate Debt: The Rısk Structure Of Interest Rates, The Journal of Finance, May, 1974

TMSF (2011), Çözümleme Deneyimi, TMSF Raf temizliği Projesi, İstanbul 
Ülkütaş Saçc1, Ö. (2014), Sistemik Öneme Sahip Bankalar: Türk Bankacılık Sektörü Iç̧in Gösterge Bazlı Bir Yöntem Önerisi, Doktora Tezi, Ankara Üniversitesi Sosyal Bilimler Enstitüsü İşletme Anabilim Dalı, Ankara 